\title{
Crinalium epipsammum sp. nov.: a filamentous cyanobacterium with trichomes composed of elliptical cells and containing poly- $\beta-(1,4)$ glucan (cellulose)
}

\author{
Ben de Winder, ${ }^{*}$ Lucas J. Stal and LuUc R. Mur \\ Laboratory for Microbiology, University of Amsterdam, Nieuwe Achtergracht 127, 1018 WS Amsterdam, \\ The Netherlands
}

(Received 17 August 1989; revised 29 March 1990; accepted 4 May 1990)

\begin{abstract}
This paper describes the isolation and characterization of a new species of cyanobacterium, Crinalium epipsammum. The assignment to the genus Crinalium, first described by Crow (1927), is based on a property which is unusual for cyanobacteria: trichomes viewed in cross-section are elliptical rather than circular. This organism was isolated from the surface layer of sandy soil of coastal dunes in The Netherlands. The organism is non-motile and drought resistant, and its cell surface is hydrophilic. The temperature optimum for growth is $25^{\circ} \mathrm{C}$. The mean DNA base composition is $33.9 \mathrm{~mol} \% \mathrm{G}+\mathrm{C}$. The cell wall is relatively thick and contains poly- $\beta$-(1,4)glucan (cellulose), which is unusual for cyanobacteria.
\end{abstract}

\section{Introduction}

Cyanobacteria are oxygenic phototrophic organisms. They are often found in nutrient-depleted environments and may represent the dominant population under extreme environmental conditions. Cyanobacteria are also known to form crusts in desert or tropical soils (Roger \& Reynaud, 1982). In such environments they thrive under conditions of low matrix water potential. Recently, we characterized the crusts of the coastal dunes of the North Sea in The Netherlands (De Winder et al., 1989), which generally consist of the eukaryotic green alga Klebsormidium flaccidum and a few species of cyanobacteria (e.g. Microcoleus spp. and Oscillatoria spp.). However, studies on population dynamics showed the frequent dominance of an unusual filamentous cyanobacterium with elliptical cells during early stages of crust formation (De Winder et al., 1989).

The colonization of dune sand by cyanobacteria and green algae is considered to play an important role in protection against erosion (Van den Ancker et al., 1985). Since this environment is exposed to long periods of drought, it is clear that the inhabiting organisms must be drought tolerant. To study the specific adaptations of the crust-building phototrophic organisms with respect to

Abbreviations: DAP, diaminopimelic acid; DCMU, 3(3,4-dichlorophenyl)-1,1-dimethylurea; DMF, dimethylformamide; PFD, photon flux density; SAG, Sammlung von Algenkulturen Göttingen. drought resistance, the dominant algae and cyanobacteria were isolated. This paper reports the isolation and characterization of the filamentous cyanobacterium whose trichomes are composed of elliptical cells. The isolate was assigned to the genus Crinalium, first described by Crow (1927), but of which cultured representatives were previously lacking (Anagnostidis \& Komarek, 1988; Castenholz, 1989). The new species Crinalium epipsammum is proposed for this organism.

\section{Methods}

Isolation and growth conditions. Crinalium epipsammum was isolated from microbial crusts, collected from so-called 'blow outs' (aeolian erosional depressions) on south-exposed slopes of sand dunes (Jungerius et al., 1981) in a coastal dune area on the Dutch North Sea coast, which were especially enriched at the edges and centre with this organism. Crust material was suspended in medium BG-11 (Rippka et al., 1979) and incubated at $20^{\circ} \mathrm{C}$ under continuous illumination with a photon flux density (PFD) of $40 \mu \mathrm{mol} \mathrm{m}^{-2} \mathrm{~s}^{-1}$. After $5 \mathrm{~d}$ the enrichment cultures were plated on BG-11 medium solidified with $1 \%$ (w/v) agar (Difco Bacto). C. epipsammum was isolated and purified by micromanipulation. Continuous and exponentially growing batch cultures were slightly contaminated with bacteria, but the degree of contamination never exceeded $1 \%$ on the basis of cell number (as judged by microscopic examination). The strain has been deposited at the Culture Collection of Algae of the Institute of Plant Physiology of the University of Göttingen, Federal Republic of Germany (strain no. SAG 22.89).

Cultures were maintained at $20^{\circ} \mathrm{C}$ under continuous illumination with white fluorescent lamps (Philips TLE 32/33) at a PFD of 
$10 \mu \mathrm{mol} \mathrm{m}^{-2} \mathrm{~s}^{-1}$ and were continuously sparged with air (approximately $\left.401 \mathrm{~h}^{-1}\right)$. Experiments were performed with two types of cultures: (i) batch cultures, grown at $20^{\circ} \mathrm{C}$ and $\mathrm{pH} \mathrm{8.0-8.5} \mathrm{under}$ continuous light at a PFD of $40 \mu \mathrm{mol} \mathrm{m}^{-2} \mathrm{~s}^{-1}$, continuously sparged with air at approximately $401 \mathrm{~h}^{-1}$ (growth rate $0.029 \mathrm{~h}^{-1}$ ); (ii) continuous cultures $\left(D=0.011 \mathrm{~h}^{-1}\right)$, grown at $20^{\circ} \mathrm{C}$ and $\mathrm{pH} 8.1$ in a light : dark cycle of $8: 16 \mathrm{~h}$, at an average PFD of $20 \mu \mathrm{mol} \mathrm{m}^{-2} \mathrm{~s}^{-1}$. Cells from batch cultures were harvested at $\mathrm{OD}_{750}=0.5(52.5 \pm 2.5 \mathrm{mg}$ protein $1^{-1}$ ), corresponding to the late exponential phase of growth. Continuous cultures were sampled in steady state. Biomass was measured as protein content or $\mathrm{OD}_{750}$. Growth at different salinities was determined by using full-strength BG-11 medium; ten-, five- and two-fold diluted BG-11; and BG-11 with 20,100 and $200 \mathrm{mM}-\mathrm{NaCl}$.

Nitrogen fixation. Nitrogenase activity was investigated by following the experimental protocol of Rippka \& Waterbury (1977). Batch cultures were washed three times in nitrate-free BG-11 medium. After resuspension in the latter medium, the cells were starved for combined nitrogen for $48 \mathrm{~h}$ under a gas phase of air $\left(401 \mathrm{~h}^{-1}\right)$ and at a PFD of $20 \mu \mathrm{mol} \mathrm{m}^{-2} \mathrm{~s}^{-1}$. The cell suspension was then concentrated tenfold, and DCMU was added to a final concentration of $10^{-5} \mathrm{M}$ to inhibit oxygenic photosynthesis. After flushing with $\mathrm{Ar}$, the anaerobic suspension was incubated in the light (PFD $20 \mu \mathrm{mol} \mathrm{m}^{-2} \mathrm{~s}^{-1}$ ) and nitrogenase activity was monitored every hour for the first $10 \mathrm{~h}$ of incubation and once after 24 and $48 \mathrm{~h}$ by measuring acetylene reduction (Stewart et al., 1968).

Hydrophobicity. Cell-surface hydrophobicity at different stages of growth of a batch culture was tested by partitioning with hexadecane (Rosenberg et al., 1980).

Motility. Motility and longitudinal rotation of the trichomes were investigated after inoculation onto Cooper dishes (Falcon, no. 3009) (Waterbury \& Stanier, 1978) containing BG-11 medium, solidified with $0.8 \%$ agar. To examine whether the trichomes rotated in response to light intensity, light was applied only through the lids of the Cooper dishes, whose bottoms and sides were protected from light by black paper. The dishes were exposed to light intensities ranging from 5 to $800 \mu \mathrm{mol} \mathrm{m}^{-2} \mathrm{~s}^{-1}$, at a temperature of $25^{\circ} \mathrm{C}$. The orientation of the long axis of the trichomes was determined by measuring the apparent trichome width with a stage micrometer after $2,4,6$ and $24 \mathrm{~h}$ of incubation. The phototactic response of the organism was examined by inoculating the centre of Petri dishes which were covered by black paper in such a way that light entered only from the sides. Results were recorded at regular intervals during a period of $10 \mathrm{~d}$ of incubation at light intensities ranging from 10 to $50 \mu \mathrm{mol} \mathrm{m}^{-2} \mathrm{~s}^{-1}$ and a temperature of $20^{\circ} \mathrm{C}$.

Scanning electron microscopy. Samples were collected on Millipore membrane filters $(0.45 \mu \mathrm{m}$ pore size $)$ and then fixed for $2 \mathrm{~h}$ in $4 \%(\mathrm{v} / \mathrm{v})$ glutaraldehyde in $0 \cdot 1 \mathrm{M}$-potassium phosphate buffer, $\mathrm{pH} \mathrm{7.2.} \mathrm{After}$ fixation, the samples were dehydrated consecutively in ethanol at concentrations of $25-100 \%(\mathrm{v} / \mathrm{v})$. The $100 \%$ ethanol washing was repeated several times to complete dehydration. Subsequently the samples were critical-point dried, gold sputtered and analysed using a Cambridge Instruments $\mathrm{S} 180$ scanning electron microscope.

Transmission electron microscopy. Samples were fixed in $6 \%(\mathrm{v} / \mathrm{v})$ glutaraldehyde for $2 \mathrm{~h}$, followed by post-fixation with $2 \%(\mathrm{w} / \mathrm{v})$ osmium tetroxide for $2 \mathrm{~h}$ at room temperature. Both fixation steps were performed in $0.1 \mathrm{M}$-potassium phosphate buffer (pH 7), which was adjusted with sucrose to an osmolarity equivalent to that of the growth medium. Fixed cells were dehydrated successively in ethanol (70$100 \%, v / v)$, and subsequently embedded in the epoxy resin of Spurr (1969). Sections $(90 \mathrm{~nm})$ were made with a diamond knife on a Reichert \& Jung Microtome Ultracut E. The sections were stained with $5 \%$ $(w / v)$ uranyl acetate followed by $8 \%(w / v)$ lead citrate (Reynolds,
1963), and were examined with a Zeiss electron microscope EM 109 at $50 \mathrm{kV}$.

Isolation of carbohydrates for $X$-ray analysis. Water-insoluble carbohydrates were isolated according to a modified procedure of Barclay \& Lewin (1985). A batch culture (10 litres), grown to an $\mathrm{OD}_{750}$ of 0.5 , was harvested by centrifugation and resuspended in $500 \mathrm{ml} 0.1 \mathrm{M}$-potassium phosphate buffer, pH 7-2. The cell suspension was passed three times through a cooled $\left(4^{\circ} \mathrm{C}\right)$ French press at $80 \mathrm{MPa}$ and then centrifuged at $20000 \mathrm{~g}$. The pellet was washed twice in $30 \mathrm{ml}$ each of the following solutions: (i) $0.1 \mathrm{M}$-potassium phosphate buffer, $\mathrm{pH} 7 \cdot 2$; (ii) distilled water; (iii) diethyl ether/ethanol $(1: 1, \mathrm{v} / \mathrm{v})$; (iv) acetone. Subsequently the pellet was dried under vacuum and finally suspended in $40 \mathrm{ml} 0.1 \mathrm{M}$ potassium phosphate buffer, $\mathrm{pH} 7 \cdot 2$. This suspension was treated with $50 \mu \mathrm{g}$ amylase (from Bacillus subtilis; specific activity 700$1500 \mathrm{U} \mathrm{mg}^{-1}$; Sigma) and $50 \mu \mathrm{g}$ amyloglucosidase (from Aspergillus niger; specific activity $6 \mathrm{U} \mathrm{mg}^{-1}$; Boehringer) for $24 \mathrm{~h}$ at $20^{\circ} \mathrm{C}$. This procedure assured the complete hydrolysis of glycogen. Ice-cold $100 \%$ ethanol $(100 \mathrm{ml})$ was added and cell-wall polysaccharides were precipitated for $8 \mathrm{~h}$ at $4^{\circ} \mathrm{C}$. The precipitate was recovered by centrifugation $\left(20 \mathrm{~min}, 20000 \mathrm{~g}, 4^{\circ} \mathrm{C}\right.$ ) and was divided into two parts. One part (fraction A), was analysed without further treatment. The other (fraction B) was resuspended in $15 \mathrm{ml} 0.5 \mathrm{M}-\mathrm{HCl}$ and hydrolysed for $1 \mathrm{~h}$ at $100^{\circ} \mathrm{C}$; the acid-resistant polysaccharides were then precipitated and collected as described for fraction A. Fractions A and B were analysed for cellulose using a Philips PW 1009/80 X-ray apparatus with $\mathrm{CU}_{\mathrm{k} \alpha}$ radiation. Powdered Whatman filter paper was used as cellulose reference.

Determination of cellulose and glycogen. A batch culture $(500 \mathrm{ml})$ was centrifuged and the pellet was extracted twice for $1 \mathrm{~h}$ in $10 \mathrm{ml}$ methanol $(100 \%)$ with intermittent centrifugation at $5000 \mathrm{~g}$. The pellet was suspended in $10 \mathrm{ml}$ boiling ethanol $(100 \%)$ and extracted overnight at $40{ }^{\circ} \mathrm{C}$. After centrifugation $(5000 \mathrm{~g})$ the pellet was hydrolysed in $5 \mathrm{ml}$ $30 \%(\mathrm{w} / \mathrm{v}) \mathrm{KOH}$ for $90 \mathrm{~min}$ at $100^{\circ} \mathrm{C}$. The hydrolysed samples were centrifuged $(10000 \mathrm{~g})$ in order to eliminate cell debris. Polysaccharides in the supernatant were precipitated $\left(2 \mathrm{~h}, 0^{\circ} \mathrm{C}\right)$ after addition of icecold ethanol to a final concentration of $75 \%(\mathrm{v} / \mathrm{v})$. The polysaccharides were collected by centrifugation and dried at $50{ }^{\circ} \mathrm{C}$. Glycogen content was determined according to Ernst et al. (1984). After complete enzymic digestion of glycogen, the remaining polysaccharides were reprecipitated with ice-cold ethanol (final concentration $75 \%, \mathrm{v} / \mathrm{v}$ ), collected by centrifugation and dried at $50{ }^{\circ} \mathrm{C}$. The cellulose content of this fraction was quantified according to Updegraff (1969).

Other determinations. Carotenoids were determined by HPLC (Korthals \& Steenbergen, 1985). Chlorophyll $a$ was determined by the DMF method using a specific absorption coefficient of $72 \cdot 114 \mathrm{~g} \mathrm{l}^{-1}$ (Volk \& Bishop, 1968). Absorption spectra were recorded on an Aminco DW2000 spectrophotometer and the phycobiliprotein content was estimated according to Tandeau de Marsac \& Houmard (1988). Protein was determined by the Folin method (Herbert et al., 1971) using bovine serum albumin as standard. Dry weight was determined on samples washed three times with distilled $\mathrm{H}_{2} \mathrm{O}$ and then lyophilized. The cells were examined for the presence of gas vacuoles by the method of Walsby (1973). DNA was extracted and purified by the hydroxyapatite method (Herdman et al., 1979). The mean $\mathrm{G}+\mathrm{C}$ content was calculated by thermal denaturation according to Marmur \& Doty 1962), using calf thymus DNA (Sigma) as reference. Peptidoglycan was measured either as diaminopimelic acid (DAP) or as D-lactic acid in $\mathrm{N}$ acetylmuramic acid (Tipper, 1968). A cell suspension (1 litre) from a batch culture was treated $(1 \mathrm{~h})$ with $4 \%(\mathrm{w} / \mathrm{v}) \mathrm{SDS}$ at $100^{\circ} \mathrm{C}$, diluted twofold with distilled $\mathrm{H}_{2} \mathrm{O}$ and centrifuged $\left(20 \mathrm{~min}, 20000 \mathrm{~g}, 10^{\circ} \mathrm{C}\right)$. To completely remove SDS the pellet was washed twelve times with distilled $\mathrm{H}_{2} \mathrm{O}$. DAP was determined qualitatively according to Work (1971). Determination of D-lactic acid in $\mathrm{N}$-acetylmuramic acid was 


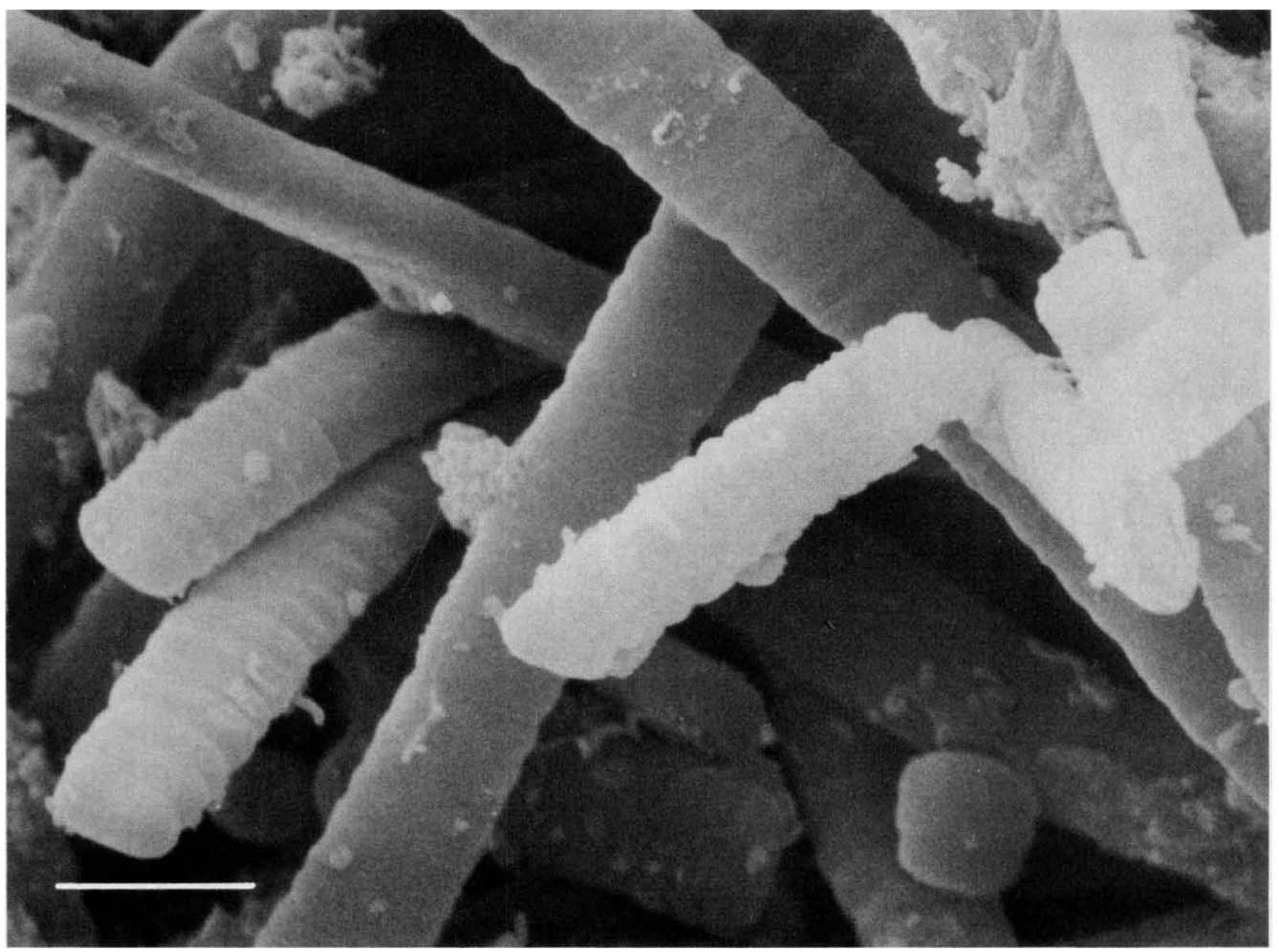

Fig. 1. Scanning electron micrograph of filaments of $C$. epipsammum from a batch culture showing the elliptical shape of the cells. Bar, $6 \mu \mathrm{m}$.

performed by a modification of the method of Tipper (1968). Batch cultures $(500 \mathrm{ml})$ were harvested $(5 \mathrm{~min}, 3800 \mathrm{~g})$. The pellets were suspended in $25 \mathrm{ml} 0.1 \mathrm{M}$-Tris $/ \mathrm{HCl}(\mathrm{pH} 7)$ and sonified for $30 \mathrm{~min}$ at $4{ }^{\circ} \mathrm{C}$ in a Branson Sonifier $(50 \%$ cycle). The broken cell suspensions were centrifuged $(10 \mathrm{~min}, 3800 \mathrm{~g}$ ) to remove remaining whole cells. The supernatants were then centrifuged at $22000 \mathrm{~g}$ for $20 \mathrm{~min}$. The resulting pellets and supernatants were hydrolysed at $100{ }^{\circ} \mathrm{C}$ with $\mathrm{HCl}(4 \mathrm{M}$, final concentration) for $6 \mathrm{~h}$. This treatment was followed by an alkaline hydrolysis with $\mathrm{NaOH}\left(4 \mathrm{M}\right.$, final concentration) for $1 \mathrm{~h}$ at $100^{\circ} \mathrm{C}$, after which the samples were filtered through a membrane filter $(0.8 \mu \mathrm{m}$ pore size, Sartorius). D-Lactate was determined by measuring NAD reduction at $340 \mathrm{~nm}$ in the presence of D-lactate dehydrogenase (Boehringer Mannheim).

\section{Table 1. Growth rates of C. epipsammum in media of} different ionic strength

The organism was grown at $20^{\circ} \mathrm{C}$ in batch culture under continuous light at a PFD of $40 \mu \mathrm{mol} \mathrm{m}^{-2} \mathrm{~s}^{-1}$, continuously sparged with air (approximately $40 \mathrm{l} \mathrm{h}^{-1}$ ), at $\mathrm{pH} 8 \cdot 0-8.5$. Data are expressed as the mean $\pm \mathrm{SD}$ of at least four independent determinations.

\begin{tabular}{lc}
\hline \hline \multicolumn{1}{c}{ Growth medium } & Growth rate $\left(\mathrm{h}^{-1}\right)$ \\
\hline BG-11 tenfold diluted & $0 \cdot 027 \pm 0 \cdot 002$ \\
BG-11 fivefold diluted & $0 \cdot 037 \pm 0.0015$ \\
BG-11 twofold diluted & $0 \cdot 035 \pm 0 \cdot 0025$ \\
BG-11 full strength & $0 \cdot 0295 \pm 0.001$ \\
BG-11 + 20 mM-NaCl & $0 \cdot 020 \pm 0 \cdot 003$ \\
BG-11 + 100 mM-NaCl & $0.011 \pm 0 \cdot 002$ \\
BG-11 $+200 \mathrm{mM}-\mathrm{NaCl}$ & 0 \\
\hline \hline
\end{tabular}

\section{Results}

\section{Growth characteristics}

Crinalium epipsammum appeared to be highly sensitive to elevated concentrations of $\mathrm{NaCl}$ (Table 1). Furthermore, although the strain was isolated and cultured in the freshwater medium BG-11, growth was not optimal in this medium. At $20^{\circ} \mathrm{C}$, the highest growth rate in batch culture was obtained in five-fold diluted BG-11 (Table 1). The temperature optimum for growth, determined in full-strength BG-11 medium, was $25^{\circ} \mathrm{C}$, yielding a specific growth rate of $0.044 \mathrm{~h}^{-1}$ in batch culture (data not shown). C. epipsammum did not grow in media devoid of combined nitrogen, nor under continuous light or under light : dark cycles. Nitrogenase activity was not detected, even when assayed under strictly anaerobic conditions.

\section{Morphology and ultrastructure}

Scanning electron microscopy revealed the typical elliptical shape of the cells of C. epipsammum (Fig. 1). The elliptical appearance of the cells was not an artifact due to the preparation of the sample. This was confirmed by thin sections of single cells (Fig. 2) and by light microscopy studies, which revealed a variation in the 


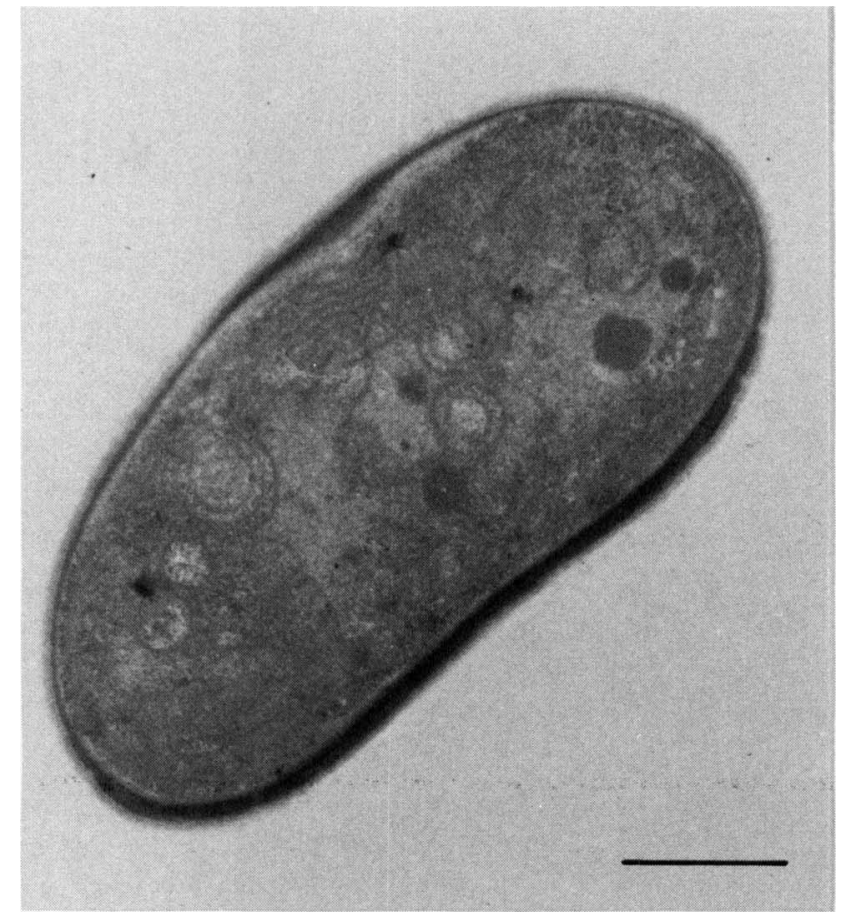

Fig. 2. Transmission electron micrograph of a cross-section of a single cell showing its elliptical shape. Bar, $1 \mu \mathrm{m}$.

apparent width of the trichomes depending on their orientation (Fig. 3). The narrow sides of the trichomes are $2-2.5 \mu \mathrm{m}$, the broad sides $5-7 \mu \mathrm{m}$ in width. $C$. epipsammum forms straight trichomes that do not taper, and which are composed of short cells $(1-1.5 \mu \mathrm{m}$ in length) (Fig. 3). False or true branching was never observed. The trichome length varied with culture conditions. At light saturation, if sparged with air, the trichomes were less than $400 \mu \mathrm{m}$ long. Under identical conditions, but exposed to nitrogen- or phosphorusstarvation, the cultures formed even shorter trichomes (less than $200 \mu \mathrm{m}$ ). Under light limitation the trichomes were extremely long (length up to $1000 \mu \mathrm{m}$ ), provided that the cultures were not agitated mechanically or sparged with air. The strain did not differentiate heterocysts or akinetes, even in the absence of combined nitrogen.

Details of the ultrastructure of $C$. epipsammum are shown in Fig. 4(a,b). Thylakoids can be seen as double membranes, mostly peripheral and parallel to the cell wall. Glycogen granules are located between the thylakoid membranes, especially near the cross walls. Polyhedral bodies, probably carboxysomes (Codd \& Stewart, 197.6), were predominantly observed in the centre of the cytoplasm and occurred in virtually every cell. Gas vacuoles were detected neither by microscopy nor by pressure collapse experiments. The cell envelope of $C$. epipsammum is relatively thick (about $100 \mathrm{~nm}$ ), due to the rather wide peptidoglycan layer (Fig. 4b). An outer

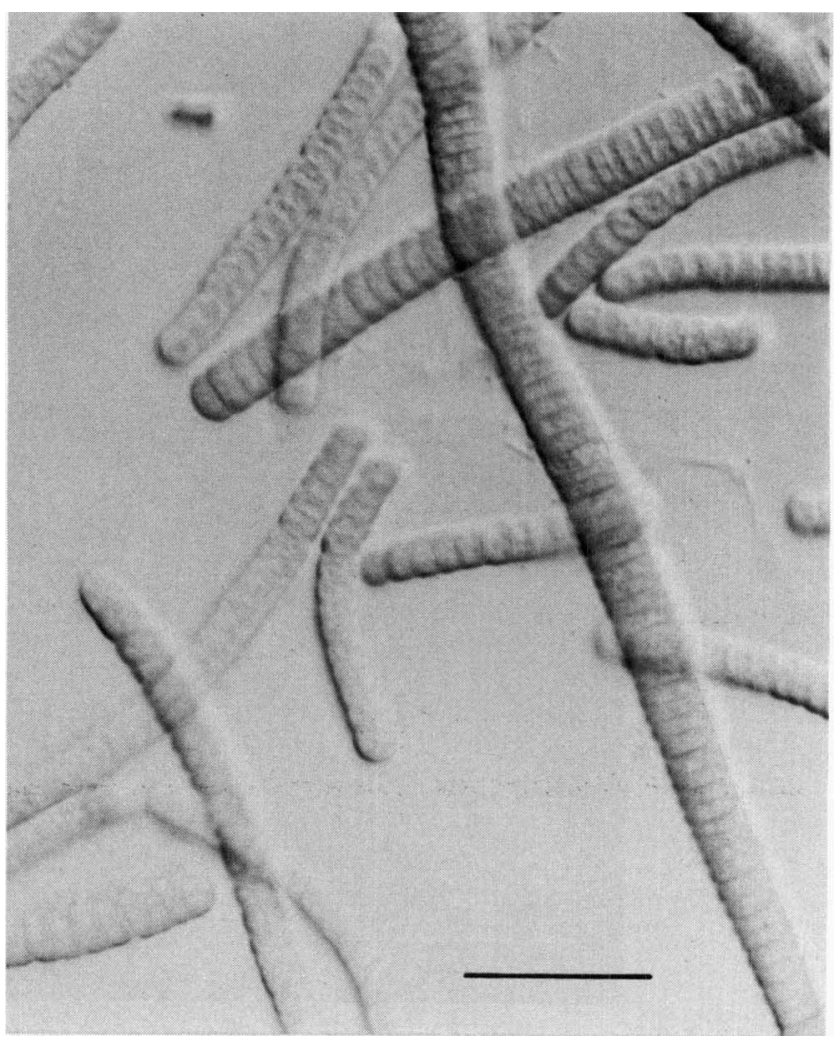

Fig. 3. Light micrograph (Nomarski interference contrast optics) of filaments of $C$. epipsammum in different orientations showing the variations in apparent width. Note also the lack of differentiation of the end cells. Bar, $20 \mu \mathrm{m}$.

membrane is poorly visible (Fig. $4 b$ ). The cell envelope contains junctional pores (Halfen \& Castenholz, 1971; Guglielmi \& Cohen-Bazire, 1982), which are located circumferentially and closely adjacent to either side of the cross-walls. Such pores have been identified in all Oscillatoria species examined and represent an important taxonomic property (Rippka, 1988). Cell division of C. epipsammum occurs by binary fission in a manner typical of the genus Oscillatoria (Drews, 1973): the cytoplasmic membrane forms a cross-septum with simultaneous formation of the peptidoglycan layer. Trichome breakage probably occurs along the circumferential junctional pores adjacent to the cross-septum.

\section{Motility and hydrophobicity}

C. epipsammum seems to be permanently non-motile, even when examined after incubation under unidirectional light. It was anticipated that the trichomes would turn their broad side towards light at low light intensities in order to maximize light harvesting, and would orient their narrow side towards light at high light intensities to protect themselves from excessive light. However, experiments with PFD values varying from 5 



Fig. 4. Details of the ultrastructure of C. epipsammum. (a) Longitudinal section across the narrow side of a filament showing the thylakoids (T) arranged parallel to the cell surface or helically twisted in the cytoplasm; carboxysomes (Cs), junctional pores (JP) and glycogen granules $(\mathrm{G})$. Bar, $0.4 \mu \mathrm{m}$; (b) Cross-section of a single cell demonstrating the thickness $(80-100 \mathrm{~nm})$ of the peptidoglycan layer. Bar, $0.2 \mu \mathrm{m}$.

\section{Table 2. Cellular components of C. epipsammum}

The organism was grown at $20^{\circ} \mathrm{C}$ in batch cultures in fivefold diluted BG-11 under continuous light at a PFD of $40 \mu \mathrm{mol} \mathrm{m}{ }^{-2} \mathrm{~s}^{-1}$, continuously sparged with air (approximately $40 \mathrm{~h} \mathrm{~h}^{-1}$ ), at $\mathrm{pH} 8 \cdot 0-8 \cdot 5$. Cells were harvested during exponential growth at $\mathrm{OD}_{750}=0 \cdot 5$. Data are expressed as the mean \pm SD of at least three determinations.

\begin{tabular}{|c|c|}
\hline Component* & $\begin{array}{l}\text { Percentage of } \\
\text { dry weight }\end{array}$ \\
\hline Protein $^{a}$ & $20 \cdot 5 \pm 0.7$ \\
\hline Total carbohydrates ${ }^{a}$ & $47 \cdot 0 \pm 2 \cdot 8$ \\
\hline Glycogen $^{b}$ & $22 \cdot 1 \pm 3 \cdot 0$ \\
\hline Cellulose $e^{c}$ & $21 \cdot 6 \pm 2 \cdot 3$ \\
\hline Chlorophyll $a^{d}$ & $1 \cdot 7+0 \cdot 1$ \\
\hline$N$-Acetylmuramic acid ${ }^{e}$ & $6.6 \pm 0.4$ \\
\hline
\end{tabular}

* The constituents were determined according to: $a$, Herbert $e t$ al. (1971); $b$, Ernst et al. (1984); $c$, Updegraff (1969); $d$, Volk \& Bishop (1968); $e$, Tipper (1968).

to $800 \mu \mathrm{mol} \mathrm{m}^{-2} \mathrm{~s}^{-1}$ did not indicate any trichome orientation in response to light intensity. Tests for hydrophobicity of the cell surface revealed that all trichomes were hydrophilic, irrespective of the stage of growth of the cultures examined.

\section{Cellular constituents}

C. epipsammum grown under continuous illumination in batch culture and harvested at $\mathrm{OD}_{750}=0.5$ yielded a very high amount of carbohydrates $(47 \%$ of cell dry weight: Table 2). Enzymic analysis revealed that only part of the carbohydrates (22.1\% of cell dry weight) represented glycogen. The remaining material was cellulose, which is probably associated with the cell envelope. X-ray analysis showed the presence of crystals of cellulose II (spacings at $5.68,4 \cdot 10,3.05$ and $2.88 \AA$; $1 \AA=0 \cdot 1 \mathrm{~nm}$ ) (Fig. $5 a$ ), that were also present in the Whatman filter paper reference sample (Fig. $5 b$ ). Cellulose I crystals (spacings at 3.83 and $2.59 \AA$ : compare Figs $5 a$ and $5 b$ ) were not present. This X-ray diffraction pattern was only visible after treatment of the polysaccharide fraction with dilute acid, indicating that crystallization was induced by this treatment and is not characteristic of the native material.

The peptidoglycan content of the organism was confirmed by qualitative determination of DAP and quantitative determination of $\mathrm{N}$-acetylmuramic acid. On dry weight basis, the cells contained $6 \cdot 6 \% N$-acetylmuramic acid (Table 2). This amount is unusually high for Gram-negative cell walls, but is representative of certain Gram-positive bacteria (Tipper, 1968). Table 3 shows the pigment composition of $C$. epipsammum grown in continuous culture. Phycoerythrin was not present, even after growth in green light. The carotenoid composition 


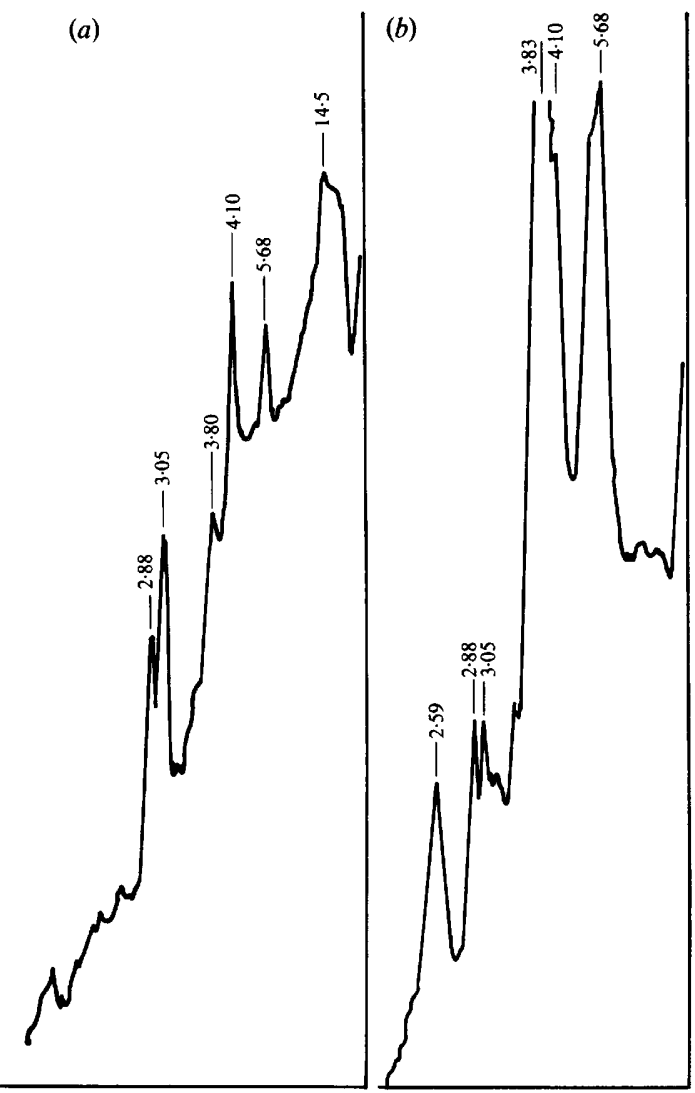

Fig. 5. X-ray diffraction pattern of cell wall polysaccharides after acid treatment $(a)$, and of powdered Whatman filter paper analysed as reference $(b)$. The peaks correspond to the diffraction rings and the numbers represent the crystal spacings $(\AA ; 1 \AA=0.1 \mathrm{~nm})$ as a function of the diameter of the diffraction rings.

of $C$. epipsammum is given in Table 4. The major carotenoids were $\beta$-carotene and echinone, but small amounts of zeaxanthine, canthaxanthine and myxoxanthophyll were also found. The relatively high amount of $\beta$-carotene detected in C. epipsammum is in agreement with the observation of Hertzberg et al. (1971) that levels of this carotenoid may be particularly high in cyanobac-

\section{Table 3. Pigment composition of C. epipsammum}

Cells were grown at $20^{\circ} \mathrm{C}$ in BG-11 medium in continuous culture $\left(D=0.011 \mathrm{~h}^{-1}\right)$ at $\mathrm{pH} 8.1$, with a light : dark cycle of $8: 16 \mathrm{~h}$, under light-limiting conditions (PFD $20 \mu \mathrm{mol} \mathrm{m}^{-2} \mathrm{~s}^{-1}$ ). Data are expressed as the mean \pm SD of at least three determinations.

\begin{tabular}{lc}
\hline \hline \multicolumn{1}{c}{ Pigment* $^{*}$} & $\begin{array}{c}\text { Concn } \\
{\left[\mu \mathrm{g}(\mathrm{mg} \text { protein })^{-1}\right]}\end{array}$ \\
\hline${\text { Chlorophyll } a^{a}}^{c}$ & $29 \cdot 8 \pm 1 \cdot 6$ \\
Allophycocyanin $^{b}$ & $32 \cdot 0 \pm 9 \cdot 5$ \\
c-Phycocyanin $^{b}$ & $62 \cdot 3 \pm 12 \cdot 8$ \\
c-Phycoerythrin $^{b}$ & 0 \\
\hline \hline
\end{tabular}

* The pigments were determined according to: $a$, Volk \& Bishop (1968); $b$, Tandeau de Marsac \& Houmard (1988).
Table 4. Carotenoid composition of C. epipsammum

The cultures were grown at $20^{\circ} \mathrm{C}$ in BG-11 medium in continuous culture $(D=0.011)$ at $\mathrm{pH} 8.1$, with a light :dark cycle of $8: 16 \mathrm{~h}$, under light-limiting conditions (PFD $20 \mu \mathrm{mol} \mathrm{m}^{-2} \mathrm{~s}^{-1}$ ). Data are from one experiment. The carotenoids were determined by HPLC (Korthals \& Steenbergen, 1985).

\begin{tabular}{lc}
\hline \hline \multicolumn{1}{c}{ Carotenoid } & $\begin{array}{c}\text { Percentage }(w / w) \text { of } \\
\text { total carotenoids }\end{array}$ \\
\hline$\beta$-Carotene & 52 \\
Zeaxanthine & 2 \\
Echinone & 37 \\
Canthaxanthine & 5 \\
Myxoxanthophyll & 4 \\
\hline \hline
\end{tabular}

teria isolated from soil. It should be noted that the pigment contents shown in Tables 3 and 4 were determined on samples from continuous cultures grown under light-limiting conditions, in order to maximize pigment synthesis.

\section{Mean DNA base composition}

The mean DNA base composition of C.epipsammum was determined as $33.9 \mathrm{~mol} \% \mathrm{G}+\mathrm{C}$, which is well below the lower limit of the range of $40-67 \mathrm{~mol} \% \mathrm{G}+\mathrm{C}$ found for all filamentous non-heterocystous cyanobacteria studied (Herdman et al., 1979).

\section{Discussion}

The organism described here is a member of the Oscillatoriales (Anagnostidis \& Komarek, 1988; Castenholz, 1989), but differs from all other filamentous nonheterocystous cyanobacteria in culture by having trichomes with elliptical rather than cylindrical cells. It fits best the description of the genus Crinalium (Crow, 1927), created for a species encountered as an epiphyte on Aphanocapsa colonies, whose trichomes occurred in a hairpin-like configuration (a property responsible for the generic name). The species described by Crow (1927) as C. endophyticum has never been cultured. Therefore it is difficult to judge whether or not hairpin formation, which was never observed in the present isolate, is a reliable property for members of this genus. According to Castenholz (1989) the genus Crinalium comprises organisms that are characterized by oscillatorian-like trichomes which are elliptical to rectangular in crosssection rather than circular or triradiate. The species described by Crow (1927) possessed cross-walls which, unless stained, were invisible by light microscopy. This property does not apply to C. epipsammum, whose crosswalls are readily visible even without staining procedures. Thus, it shares more properties with a second 
species, C. magnum, described by Fritsch \& John (1942), in which cross-walls were also clearly visible and which was placed into the genus Crinalium solely on the basis of its elliptical trichomes. However, the description of $C$. magnum by Fritsch \& John (1942) does not fit $C$. epipsammum with respect to size. $C$. magnum was reported to possess very broad trichomes (up to $18 \mu \mathrm{m}$ ), whereas the broad side of our strain never exceeds $7 \mu \mathrm{m}$. Although the new isolate does not entirely fit either the description of $C$. endophyticum (Crow, 1927) or that of $C$. magnum (Fritsch \& John, 1942), we feel confident that the generic assignment to Crinalium is justified, and propose to assign the organism to the new species, $C$. epipsammum. However, it should be pointed out that $C$. epipsammum shares certain properties with strains of Oscillatoria, i.e. a relatively thick peptidoglycan layer, junctional pores (Guglielmi \& Cohen-Bazire, 1982; Rippka, 1988) and the type of cell division and trichome fragmentation (Drews \& Weckesser, 1982). However, all Oscillatoria species are motile and form cylindrical trichomes which are sometimes surrounded by a thin sheath, whereas $C$. epipsammum is composed of elliptical cells, does not exhibit sheath formation and is non-motile. Furthermore, its G + C content of $33.9 \mathrm{~mol} \%$ is significantly lower than that described for all organisms assigned to Oscillatoria (Herdman et al., 1979), which seems sufficient reason for the separation of the new isolate from the latter genus.

The identification of poly- $\beta$ - $(1,4)$ glucan in C. epipsammum is also novel for cyanobacteria, although its presence has previously been suggested, on the basis of light and electron microscopy, in some heterocystous species (Frey-Wyssling \& Stecher, 1954; Tuffery, 1969). In C. epipsammum this polymer seems to exist in vivo in a non-crystalline form, in contrast to the crystalline form reported for Acetobacter xylinum (Aschner \& Hestrin, 1946), for the following reason. Filter paper, which was used as the reference for the determination of the $\beta$ - $(1,4)$ glucan, is a mixture of cellulose of types I and II. Cellulose of type $I$, the natural crystalline $\beta-(1,4)$ polyglucose of higher plants, gives rise to cellulose of type II by alkaline or acid treatment. A diffraction pattern typical of cellulose type I was lacking in C. epipsammum, and that corresponding to its derivative, cellulose type II, was only observed after acid treatment of this polymer. It is not yet clear where the cellulose is located. It seems unlikely to be an extracellular component as in $A$. xylinum, since electron microscopy did not reveal cellulose fibrils external to the cell wall. Therefore it is possible that cellulose is an integral part of the cell wall.

C. epipsammum is a terrestrial cyanobacterium, growing in moving sand, a habitat in which deprivation of light and the availability of water are major problems for the survival of the organism. Both the thick cell wall and the elliptical shape of the cells may be important adaptations to these extreme environmental conditions. Many terrestrial cyanobacteria possess a sheath. Under conditions where water is a limiting factor, thick mucilaginous sheaths surrounding the trichomes may favour the rapid uptake of water after desiccation (Durrell \& Shields, 1961) and help to maintain a relatively humid environment for the organisms (Shephard, 1987). In C. epipsammum, in which a sheath was not detected, the thick, presumably cellulose-containing cell wall may serve the same function as a sheath, since pure cellulose has a high capacity to retain water (Updegraff, 1969). Water retention of $C$. epipsammum might also be enhanced as a result of the hydrophilic properties of its cell wall. Thus the structural and biochemical characteristics of this organism may be key elements for its periodic dominance in the extreme environment from which it was isolated.

A formal description of C. epipsammum is given below, together with an amended description of the genus Crinalium. The original description of this genus by Crow (1927) is poor, and based on uncultured material.

Amended description of the genus Crinalium Crow 1927 Cri.na'li.um. L. adj. crinalis of hair; Gr. suff. -ion diminutive; ML neut. n. Crinalium small hairlike (Castenholz, 1989)

Filamentous cyanobacteria (oxygenic photoautotrophs containing chlorophyll $a$ as primary photosynthetic pigment and phycobiliproteins as light-harvesting accessory pigments) with trichomes of varying length, composed of cells that are elliptical in cross section; cell division occurs by binary fission in a single plane. The trichomes do not taper, and lack differentiated cells (heterocysts and akinetes).

\section{Crinalium epipsammum sp. nov.}

e.pi.psam'mum. Gr. prep. epi on, upon; Gr. masc. n. psammos sand; ML adj. epipsammum on sand

Filamentous cyanobacterium composed of short (1$1.5 \mu \mathrm{m})$ elliptical cells that are 5-7 $\mu \mathrm{m}$ in height and 2$2.5 \mu \mathrm{m}$ in width. End cells are not different in morphology from intercalary cells. The trichomes are nonmotile, lack a sheath, may vary in length and do not differentiate heterocysts and akinetes. False or true branching is never observed. Cell division occurs by binary fission; the cytoplasmic membrane forms a crossseptum with simultaneous formation of the peptidoglycan layer. Reproduction occurs by random trichome breakage. The thylakoid membranes are predominantly arranged parallel and close to the periphery of the cells, but may also occur in the centre of the cells, in which case they are curved inwards. Gas vacuoles are not present. 
Polyhedral bodies are located in the centre of the cells. Chlorophyll $a$ and phycocyanin are the major photosynthetic pigments. $\beta$-Carotene and echinone are the major carotenoids. Dinitrogen fixation occurs neither aerobically nor anaerobically The species is sensitive to elevated concentrations of $\mathrm{NaCl}$, is drought tolerant, and its optimum growth temperature is $25^{\circ} \mathrm{C}$. It was isolated from the surface layers of coarse silica dune sand from the Dutch North Sea coast. The mean DNA base composition is $33.9 \mathrm{~mol} \% \mathrm{G}+\mathrm{C}\left(T_{\mathrm{m}}\right)$. The type strain has been deposited in the Culture Collection of Göttingen (SAG) under the number 22.89 .

The authors would like to thank Mrs A. van Egmont for technical assistance, Dr H. Korthals from the Limnological Institute of Nieuwersluis for the HPLC analysis of the carotenoids, Dr J. H. Sietsma from the University of Groningen for the X-ray analysis of the carbohydrates, and Mrs G. Niemann and Mrs S. Seufer from the University of Oldenburg (FRG) for supplying the electron micrographs. We appreciate the critical reviews of Dr U. J. Jürgens from the University of Freiburg (FRG), Dr J. H. Sietsma and several anonymous referees. Many thanks are due to Professor H. G. Trüper from the University of Bonn (FRG) for advice in the formal description of the new species. The work was supported by the Foundation for Geographical Research (AWON), which is subsidized by the Dutch Organisation of Scientific Research (NWO).

\section{References}

ANAGnostidis, K. \& KomareK, J. (1988). Modern approach to the classification system of cyanophytes. 3. Oscillatoriales. Archives of Hydrobiology Supplement 80, 327-472.

ASCHNER, M. \& HESTRIN, S. (1946). Fibrillar structure of cellulose of bacteria and animal origin. Nature, London 157, 659.

BARCLAY, W. R. \& LEWIN, R. A. (1985). Microalgal polysaccharide production for the conditioning of agricultural soils. Plant and Soil 88, $159-169$.

Castentolz, R. (1989). Subsection III. Order Oseillatoriales. In Bergey's Manual of Systematic Bacteriology, vol. 3, pp. 1771-1780. Edited by J. T. Staley, M. P. Bryant, N. Pfennig \& J. G. Holt. Baltimore: Williams \& Wilkins.

Codd, G. A. \& Stewart, W. D. P. (1976). Polyhedral bodies and ribulose 1,5-diphosphate carboxylase of the blue-green alga Anabaena cylindrica. Planta 130, 323-326.

Crow, W. B. (1927). Crinalium, a new genus of Cyanophyceae, and its bearing on the morphology of the group. Annals of Botany 41, 161165.

De Winder, B., Pluis, J., De Reus, L. \& Mur, L. R. (1989). Characterization of a cyanobacterial, algal dune crust in the coastal dunes of The Netherlands. In Microbial Mats, Physiological Ecology of Benthic Microbial Communities, pp. 77-83. Edited by Y. Cohen \& E. Rosenberg. Washington, DC: American Society for Microbiology.

DREWs, G. (1973). Fine structure and chemical composition of the cell envelopes. In The Biology of Blue-green Algae, pp. 96-116. Edited by N. G. Carr \& B. A. Whitton. Oxford: Blackwell Scientific Publications.

Drews, G. \& WeCKesSer, J. (1982). Function, structure and composition of cell walls and external layers. In The Biology of Cyanobacteria, pp. 333-359. Edited by N. G. Carr \& B. A. Whitton. Oxford: Blackwell Scientific Publications.
DURRell, L. A. \& Shields, L. M. (1961). Characteristics of soil algae relating to crust formation. Transactions of the American Microscopy Society 80, 73-90.

ERNST, A., Kirschenlohr, H., Diez, J. \& Böger, P. (1984). Glycogen content and nitrogenase activity in Anabaena variabilis. Archives of Microbiology 140, 120-125.

Frey-Wyssling, A. \& STecher, H. (1954). Über den Feinbau des Nostoc-Schleimes. Zeitschrift für Zellforschung und Mikroscopische Anatomie 39, 515-519.

FrITSCH, F. E. \& JoHN, R. P. (1942). An ecological and taxonomic study of the algae of the British soils. Annals of Botany, N.S. 6, 371395.

Guglielmi, G. \& Cohen-Bazire, G. (1982). Structure et distribution des pores et des perforations de l'enveloppe de peptidoglycane chez quelques cyanobactéries. Protistologica 18, 151-165.

Halfen, L. N. \& Castenholz, R. W. (1971). Gliding motility in the blue-green alga, Oscillatoria princeps. Journal of Phycology 7, 258260.

Herbert, D., Phipps, P. J. \& Strange, R. E. (1971). Chemical analysis of microbial cells. Methods in Microbiology 5B, 209-344.

Herdman, M., JanVier, M., Waterbury, J. B., RipPKa, R., Stanier, R. Y. \& MANDEL, M. (1979). Deoxyribonucleic acid base composition of cyanobacteria. Journal of General Microbiology 111, 63-71.

Hertzberg, S., LiaAnen-Jensen, S. \& Siegelmann, H. W. (1971). The carotenoids of blue green algae. Phytochemistry 10, 3121-3127.

Jungerius, P. D., Verheggen, A. T. J. \& Wiggers, A. J. (1981). The development of blowouts in 'De Blink' a coastal dune area near Noordwijkerhout, The Netherlands. Earth Surface Processes and Landforms 6, 375-396.

Korthals, H. J. \& Steenbergen, C. L. M. (1985). Separation and quantification of pigments from natural phototrophic microbial population. FEMS Microbiology Letters 31, 177-181.

MARMUR, J. \& DOTY, P. (1962). Determination of the base composition of deoxyribonucleic acid from its thermal denaturation temperature. Journal of Molecular Biology 5, 109-118.

REYNolds, E. S. (1963). The use of lead citrate at high pH as an electron opaque stain in electron microscopy. Journal of Cell Biology 17, 208-212.

RIPPKA, R. (1988). Recognition and identification of cyanobacteria. Methods in Enzymology 167, 28-68.

RIPPKA, R. \& WATERBURY, J. B. (1977). The synthesis of nitrogenase by non-heterocystous cyanobacteria. FEMS Microbiology Letters 2 , 83-86.

Rippka, R., Deruelles, J., Waterbury, J. B., Herdman, M. \& StANIER, R. Y. (1979). Generic assignments, strain histories and properties of pure cultures of cyanobacteria. Journal of General Microbiology 111, 1-61.

ROGER, P. A. \& REYNAUD, P. A. (1982). Free living blue-green algae in tropical soils. In Microbiology of Tropical Soils and Plant Productivity, pp. 147-168. Edited by Y. R. Dommergues \& H. G. Diem. The Hague: Martinus Nijhoff/ Dr W. Junk Publishers.

ROSENBERg, M., GUTNICK, D. \& RosenBerg, E. (1980). Adherence of bacteria to hydrocarbons: a simple method for measuring cellsurface hydrophobicity. FEMS Microbiology Letters 9, 29-33.

SHEPHARD, K. L. (1987). Evaporation of water from the mucilage of a gelatinous algal community. British Phycological Journal 22, 181-185.

SPURR, A. R. (1969). A low viscosity epoxy resin embedding medium for electron microscopy. Journal of Ultrastructure Research 26, 31-43.

Stewart, W. D. P., Fitzgerald, G. P. \& Burris, R. H. (1968). Acetylene reduction by nitrogen fixing blue-green algae. Archiv für Mikrobiologie 62, 336-348.

TANDEAu de Marsac, N. \& Houmard, J. (1988). Complementary chromatic adaptation: physiological conditions and action spectra. Methods in Enzymology 167, 318-328.

TIPPER, D. J. (1968). Alkali catalyzed elimination of D-lactic acid and its derivatives and the determination of muramic acid. Biochemistry 7, 1441-1449.

TUFFerY, A. A. (1969). Light and electron microscopy of the sheath of a blue-green alga. Journal of General Microbiology 57, 41-50.

UPDEGRAFF, D. M. (1969). Semimicro determination of cellulose in biological materials. Analytical Biochemistry 32, 420-424. 
VAN den ANCKer, J. A. M., Jungerius, P. D. \& MUR, L. R. (1985) The role of algae in the stabilization of coastal dune blowouts. Earth Surface Processes and Landforms 10, 189-192.

VolK, S. L. \& Bishop, N. I. (1968). Photosynthetic efficiency of a phycocyanin-less mutant of Cyanidium. Photochemistry and Photobio$\log y$ 8, 213-221.

WALSBY, A. E. (1973). A portable apparatus for measuring relative gas vacuolation, the strength of gas vacuoles and turgor pressure in planktonic blue-green algae and bacteria. Limnology and Oceanography 18, 653-658.

Waterbury, J. B. \& Stanier, R. Y. (1978). Patterns of growth and development in pleurocapsalean cyanobacteria. Microbiological Reviews 42, 2-44.

WORK, E. (1971). Cell walls. Methods in Microbiology 5A, 361-416. 